tial to the "crossing-over" explanation of the linkage of characters in heredity, and it is to be hoped that the cytologist will be able to decide the point one way or the other. Another phenomenon which requires clearing up is the absence of any "crossing-over" in the male for any character whatever, though the number and arrangement of the chromosomes in the two sexes are apparently identical. It is, of course, not impossible that what now appears to be a weak point might turn out to be a strong one if the cytologist could show that the behaviour of the chromosomes during the maturation divisions differed in the tivo sexes.

There are other objections to the chromosome theory which would require too much space to set out in detail, but whether the theory advocated by Prof. Morgan prove to be well founded or not, there can be no doubt that he has given us a most interesting and stimulating book. Not only does it give a clear and well-illustrated account of one of the most important groups of facts relating to heredity yet elucidated by the experimental method, but at the same time it offers the most successful attempt so far made to relate these facts to our knowledge of cellular anatomy. Together with the author we hope sincerely that it may be widely read outside the circle of professed students of heredity, and especially that it may be digested by those whose particular province is the minute structure of the cell.

\section{THE TECHNOLOGY OF SULPHUR AND SULPHUR COMPOUNDS.}

Manuals of Chemical Technology. V. Sulphuric Acid and Sulphur Products. By Dr. G. Martin and Major J. L. Foucar. Pp. viii +77. (London: Crosby Lockwood and Son, 1916.) Price 7s. 6d. net.

A MELANCHOLY circumstance attaches to A this book, which to a large extent disarms criticism. Before the section on sulphuric acid, for which Major Foucar, a former assistant manager of the Beckton Gas Works, was responsible, was ready for the press, war broke out, and Major Foucar was killed when leading his men into action. It devolved, therefore, on Dr. Geoffrey Martin, the editor of the series, to put together the material which had been collected, and at the same time to extend the scope of the volume.

The result is a book of some seventy pages-a space wholly inadequate to deal properly with the important subject with which it professes to deal. It is divided into four chapters, treating, respectively, of the sulphur industry, sulphuric acid, the manufacture of sulphur dioxide, and of certain other sulphur compounds, viz., carbon disulphide, sodium thiosulphate, and hyposulphite and sulphuretted hydrogen. The total amount of space given to these subjects is about sixty-five pages, the rest of the book, exclusive of the short preface and indexes, being made up of tables of weights and measures and comparisons of thermometer and hydrometer scales of the conventional type.
Each chapter consists of short, disconnected notes on features of interest rather than of systematic accounts of the several industries. It is not very obvious what class of readers it is intended to serve. The student may gain from it a superficial knowledge of the technology of sulphur and of such of its compounds as are mentioned, but the actual manufacturer will find its information far too slight and "scrappy" to be of practical service. The language of the preface would seem to imply that the person aimed at is that ubiquitous individual known as the general reader. But if this is so we fear that person will gain a somewhat confused idea of its purport, for, small as is the amount of information conveyed, a glance through the pages of the book shows that it obviously presupposes some previous knowledge of the subject.

The account of the sulphur industry, constituting chapter i., will serve to illustrate what we mean. The whole chapter occupies five pages, of which half is given to a meagre description of the sources and mode of extraction of natural sulphur; about a page is given to a still more meagre account of the Chance-Claus method of sulphur recovery, the so-called thiogen process of treating smelter-smoke, and the Burkheiser and Feld methods of obtaining sulphur from sulphuretted hydrogen in coal-gas purification, whilst the remainder is concerned with the properties and uses of sulphur. The reference to the Sicilian industry and the allusion to the "calcarone" method convey no meaning to the uninitiated or any information to those who are initiated. The account of the Gill kiln and of the method of its working is so slight as to be practically valueless. The Frasch process of winning Louisiana sulphur is one of the most striking achievements of modern technology. It constitutes indeed one of the romances of applied science. Although Dr. Martin's method of treatment seems to disallow anything in the nature of descriptive writing, we think it would have added greatly to the interest and value of his book if he had given a fuller account of it. It is still not so generally known in this country as it ought to be, in spite of the fact that, as he truly states, it dominates the world's sulphur market.

Our general impression of this book is one of disappointment as a wholly inadequate treatment of a vastly important subject.

\section{HOMER AND HISTORY.}

Homer and History. By Dr. Walter Leaf. Pp xvi +375 . (London: Macmillan and Co., Ltd. I9I5.) Price I2s. net.

THE researches of Dr. Leaf have opened a 1 new phase in the discussion of the Homeric problem. His first task is to discard the intere pretations which have hitherto held the fielde Until the publication of Wolf's "Prolegomena" the unity of the Epic was, as a matter of course accepted. We were then invited to believe tha the Iliad at least was a collection of lays weldee into a single whole by some skilful editor. With the study of comparative philology came the

NO. 2423 , VOL. 97] 